\title{
Projection of Future Climate over the Koshi River Basin Based on CMIP5 GCMs
}

\author{
Rupak Rajbhandari ${ }^{*}$, Arun Bhakta Shrestha², Santosh Nepal'2, Shahriar Wahid ${ }^{2}$ \\ ${ }^{1}$ Department of Meteorology, Tri-Chandra Campus, Tribhuvan University, Kathmandu, Nepal \\ ${ }^{2}$ International Centre for Integrated Mountain Development, Kathmandu, Nepal \\ Email: "rupak.rajbhandari@gmail.com
}

Received 11 January 2016; accepted 25 March 2016; published 28 March 2016

Copyright (C) 2016 by authors and Scientific Research Publishing Inc.

This work is licensed under the Creative Commons Attribution International License (CC BY). http://creativecommons.org/licenses/by/4.0/

(c) (i) Open Access

\section{Abstract}

This paper analyses the climate projections over the Koshi river basin obtained by applying the delta method to eight CMIP5 GCMs for the RCP4.5 and RCP8.5 scenarios. The GCMs were selected to cover the full envelope of possible future ranges from dry and cold to wet and warm projections. The selected coarse resolution GCM outputs were statistically downscaled to the resolution of the historical climate datasets. The scenarios were developed based on the anomaly between the present reference period (1961-1990) and the future period (2021-2050) to generate transient climate change scenarios for the eight GCMs. The analyses were carried out for the whole basin and three physiographic zones: the trans-Himalaya, high-Himalaya and middle mountains, and southern plains. Future projections show a 14\% increase in rainfall during the summer monsoon season by 2050 . The increase in rainfall is higher over the mountains than the plains. The meagre amount of rainfall in the winter season is projected to further decrease over both the mountain and southern plains areas of the basin for both RCPs. The basin is likely to experience warming throughout the year, although the increase in winter is likely to be higher. The highest increase in temperature is projected to be over the high Himalayan and middle mountain area, with lower increases over the trans-Himalayan and southern plains areas.

\section{Keywords}

Climate Projection, Climate Change, Himalaya, Koshi, Future Scenario

\section{Introduction}

Mountain regions are particularly sensitive to climate change and variability [1]. The Himalayan mountains are

"Corresponding author.

How to cite this paper: Rajbhandari, R., Shrestha, A.B., Nepal, S. and Wahid, S. (2016) Projection of Future Climate over the Koshi River Basin Based on CMIP5 GCMs. Atmospheric and Climate Sciences, 6, 190-204. 
among the most fragile environments in the world. They are also a repository of water and biodiversity and contain a range of ecosystems, all of which are facing enormous pressures from various drivers, with climate being one of the most important [2]. The climate varies considerably across this vast region, reflecting the rapid changes in elevation and the physical barrier posed by the mountain ranges. The rainfall distribution varies markedly from east to west due to the diverse topography, and the temperature distribution is strongly influenced by elevation, giving rise to a great variation in ecological zones [3]-[6]. Wind speed also contributes to differences in temperature and distribution of precipitation [7].

The potential impact of climate change on the water resources of the Himalayan region is of great concern [8]. Climate models indicate that the precipitation and temperature are likely to change in the future [9], but with differences in the magnitude of change across the region. There is considerable uncertainty in the future climate projections, however, due to the high degree of spatial variability which means that the coarse resolution global climate models (GCMs) have difficulty in properly representing the Himalayan region [10] [11]. To address this, GCMs are downscaled to regional or local level using statistical and dynamic methods. Many studies have indicated that these fine resolution climate data are essential for understanding the impact of climate change on the hydrological regime, both upstream and downstream [12]-[14].

The Koshi river basin is shared between China, Nepal, and India and is one of the key transboundary basins in the Hindu Kush Himalayan (HKH) region. Originating in the high-altitude Tibetan plateau and the Himalayas, the Koshi river and its tributaries flow through Nepal's middle mountains and hills to the lowland Terai region of Nepal and India, where a vast alluvial fan has developed over the centuries. At the confluence with the Ganges, the Koshi basin drains an area of some 87,970 square kilometers; approximately $32 \%$ in China, $45 \%$ in Nepal, and 23\% in India. Figure 1 shows the basin location and physiographic zones.

The basin has a high potential for investment in hydropower development, and in irrigation in the downstream areas. It also contains important ecosystems and protected areas that provide a wide range of biodiversity and ecosystem services, which sustain the livelihoods of the local communities, as well as contributing important services at regional and global scale. However, the diverse topography, young geological formations, high degree of glaciation, and strong monsoon influence make the basin particularly prone to erosion and sedimentation and to a range of natural hazards, including glacial lake outburst floods (GLOFs), landslides and debris flows, droughts, and floods [15]. The Koshi basin has a very high sediment load, reported to range from 135 to 190

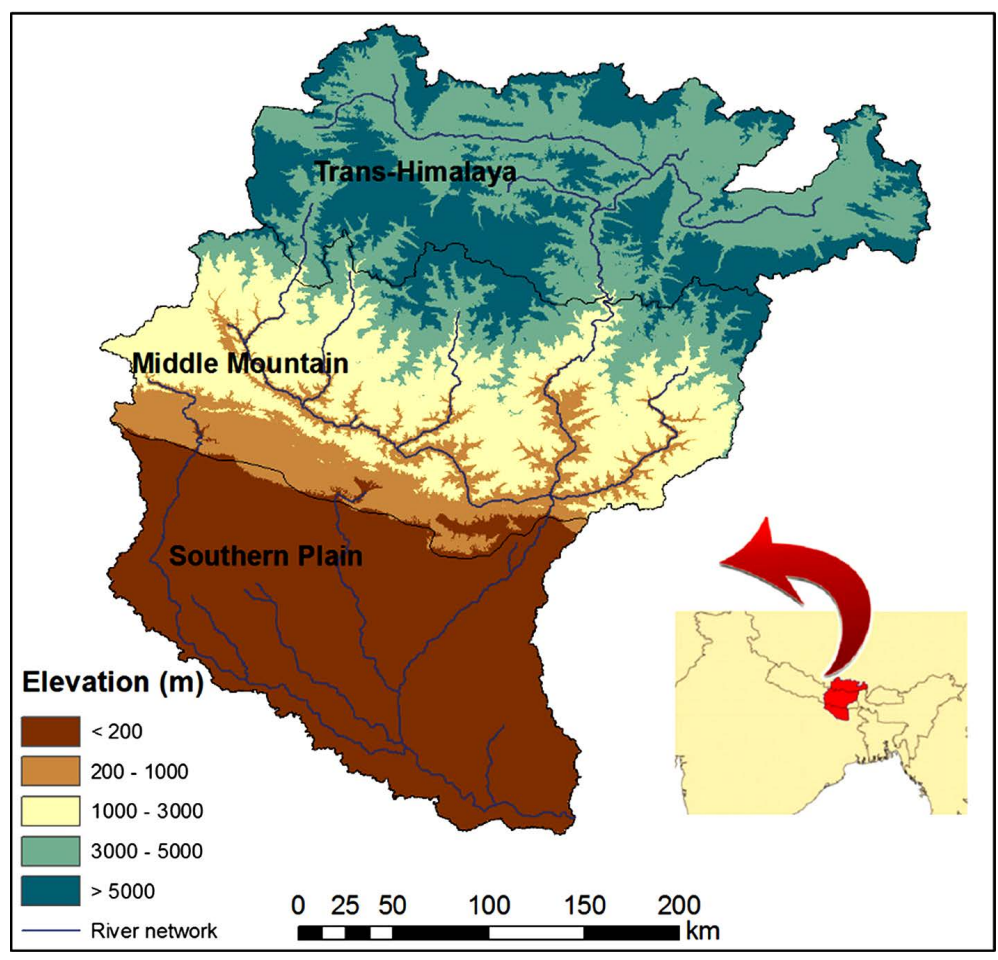

Figure 1. Position, elevation, and physiographic zones of the Koshi basin. 
million tonnes per year [16]-[18]. In the context of climate change, these hazards may increase in magnitude and frequency [3] [19]. The potential for natural hazards impacts on the potential for investment, and poses considerable problems for the livelihoods and wellbeing of the people in the region, with poor people the most vulnerable and hardest hit. At the same time, an increasing population, urbanization, and encroachment are adding to the pressure on the basin's freshwater and other ecosystems.

It is important to understand the future water availability in the basin in the context of global climate change. However, before water availability can be estimated, it is first necessary to analyze the future climate scenarios. The present study aimed to understand the spatial and temporal dimensions of precipitation and temperature change in the Koshi river basin, as these are the most important inputs to the hydrological models. Historic and future climate projection data were used as a basis for analyzing changes in the pattern of precipitation and temperature. In order to analyze the different changes that are likely to occur in different parts of the basin, it was divided into three physiographic zones: the trans-Himalayan area to the north (mainly the Tibetan plateau area in China); the high Himalayan and middle mountains area in the center (mostly in Nepal, hereafter referred to as the "middle mountains"), and the low lying plains area to the south (in Nepal and India).

\section{Data and Methodology}

\subsection{Selection of GCMs}

There is a great variability in the projections of precipitation and temperature made by different Global Circulation Models (GCMs). Each GCM has different strengths and weaknesses; some perform better over tropical regions and others over polar regions. It is important to select the model which performs best for the region of interest. There are two main methods for selecting the most appropriate GCMs. The first aims to cover the full envelope of possible future situations ranging from dry and cold projections to wet and warm projections, while the second selects GCMs on the basis of indicators of past performance. The approaches have different pros and cons, but in the HKH the first approach is preferable as climate models have considerable difficulty in simulating past climate [20]. Generally, the first approach is preferred for statistical downscaling, whereas the past performance approach is preferred for dynamic downscaling.

The Intergovernmental Panel for Climate Change (IPCC) has published projections of future climate change scenarios in a series of reports. There was a fundamental change between the fourth and fifth assessment reports (AR4 and AR5) [4] [21] [22] and in order to reflect such differences as well as model variability, the study looked at two future scenarios. The first scenario considers what the future climate will be under conditions with a representative concentration path (RCP) that assumes that radiative forcing will stabilize at $8.5 \mathrm{~W} / \mathrm{m}^{2}$ in 2100 (RCP8.5); the second less extreme scenario assumes that radiative forcing will stabilize at $4.5 \mathrm{~W} / \mathrm{m}^{2}$ in 2100 (RCP4.5).

The model selection was carried out as part of a previous study over a larger spatial domain [11]. The GCMs were tested using AR5 data downloaded from the CMIP5 model archive (http://cmip-pcmdi.llnl.gov/cmip5/data_portal.html). In total, 43 GCMs were tested for RCP4.5 and 41 for RCP8.5. For each model run, the normal annual difference (delta) (2021-2050 relative to reference period 19611990) was determined for precipitation (\%) and temperature (K). Based on these projected differences, four combinations (dry and cold; dry and warm; wet and cold; wet and warm) were derived for each RCP based on the 10th and 90th percentile values of the projected changes. Finally, the model runs that were closest to the percentile values were selected for downscaling as shown in Figure 2 (red crosses). The percentile values were used to avoid outlier GCMs, which are likely to be unreliable (Figure 2). Eight GCMs were selected, four for RCP4.5 and four for RCP8.5, as shown in Table 1.

\subsection{Calculation of Monthly Delta Values}

The coarse resolution eight selected GCM anomalies were downscaled to a finer resolution of $0.25^{\circ} \times 0.25^{\circ}$ latitude and longitude by interpolating with a first order bilinear spline technique with tension 10 and 4 neighborhoods [11]. The delta values reflect the changes in temperature and precipitation over 60 years. The delta approach is widely used [23]-[25] and is an efficient way to assess climatic changes with multiple GCM outputs. This approach was necessary due to the large scale discrepancy between the climate models and the hydrological models which operate at a much higher resolution. The major focus in this study was on the uncertainty 

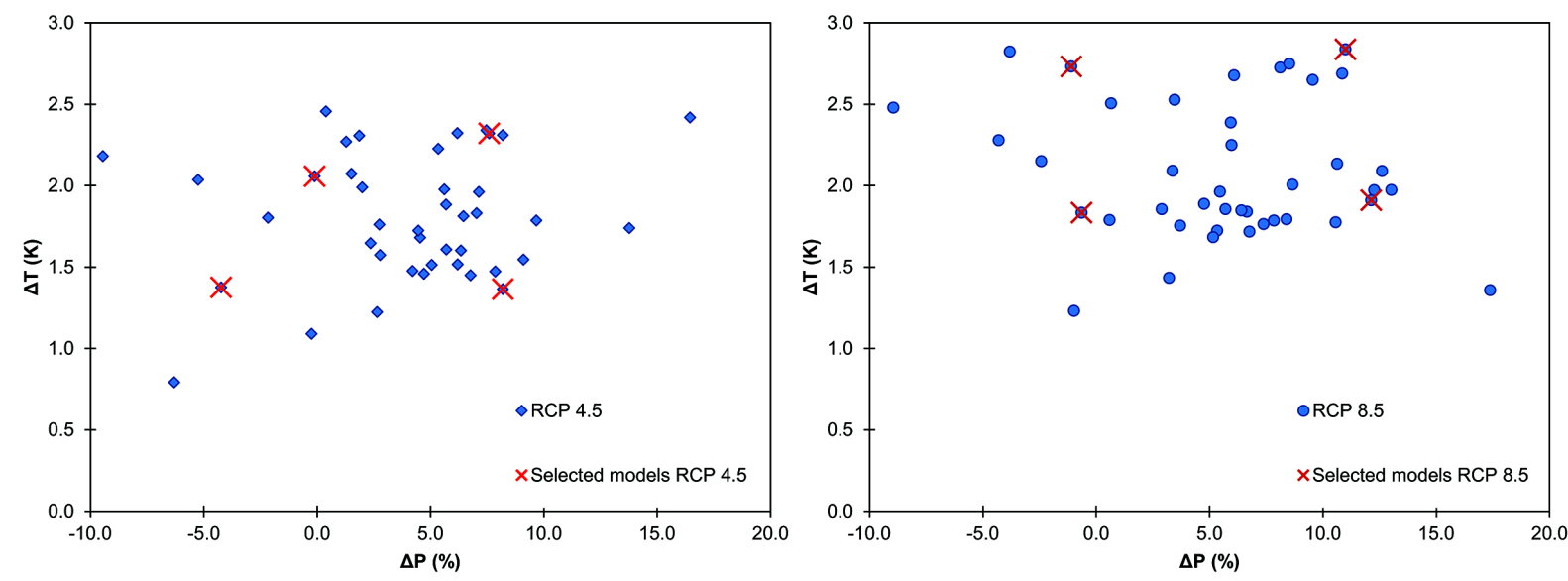

Figure 2. Projected changes in P (precipitation) in \% and T (temperature) in ${ }^{\circ} \mathrm{K}$ for RCP4.5 (left) and RCP8.5 (right) with different model runs.

Table 1. Model selection based on 10th and 90th percentile values of projected changes in precipitation and temperature from 1961-1990 to 2021-2050.

\begin{tabular}{|c|c|c|c|c|c|}
\hline \multirow{2}{*}{ Selected GCM } & \multirow{2}{*}{ RCP } & \multirow{2}{*}{ Description } & \multicolumn{2}{|c|}{ Resolution } & \multirow{2}{*}{ Institute } \\
\hline & & & Lon & Lat & \\
\hline GISS-E2-R-r4i1p1_rcp45 & RCP4.5 & dry, cold & $2.5^{\circ}$ & $2.0^{\circ}$ & $\begin{array}{l}\text { Goddard Institute for Space Studies, } \\
\text { NOAA, USA }\end{array}$ \\
\hline IPSL-CM5A-LR-r4i1p1_rcp45 & RCP4.5 & dry, warm & $3.75^{\circ}$ & $1.894737^{\circ}$ & Institut Pierre Simon Laplace, France \\
\hline IPSL-CM5A-LR-r3i1p1_rcp45 & RCP4.5 & wet, cold & $3.75^{\circ}$ & $1.894737^{\circ}$ & Institut Pierre Simon Laplace, France \\
\hline CanESM2-r4i1p1_rcp45 & RCP4.5 & wet, warm & $2.8125^{\circ}$ & $2.789327^{\circ}$ & $\begin{array}{l}\text { Canadian Centre for Climate } \\
\text { Modelling and Analysis, Canada }\end{array}$ \\
\hline GFDL-ESM2G-r1i1p1_rcp85 & RCP8.5 & dry, cold & $2.5^{\circ}$ & $2.01111^{\circ}$ & $\begin{array}{l}\text { Geophysical Fluid Dynamics } \\
\text { Laboratory, NOAA, USA }\end{array}$ \\
\hline IPSL-CM5A-LR-r4i1p1_rcp85 & RCP8.5 & dry, warm & $3.75^{\circ}$ & $1.894737^{\circ}$ & Institut Pierre Simon Laplace, France \\
\hline CSIRO-Mk3-6-0-r3i1p1_rcp85 & RCP8.5 & wet, cold & $1.875^{\circ}$ & $1.864677^{\circ}$ & $\begin{array}{l}\text { Commonwealth Scientific and Industrial } \\
\text { Research Organisation, Australia }\end{array}$ \\
\hline CanESM2-r4i1p1_rcp85 & RCP8.5 & wet, warm & $2.8125^{\circ}$ & $2.789327^{\circ}$ & $\begin{array}{c}\text { Canadian Centre for Climate Modelling } \\
\text { and Analysis, Canada }\end{array}$ \\
\hline
\end{tabular}

stemming from climate simulations, so as many GCM outputs as possible were retained, while a simple approach was used for downscaling. The grid cells of the climate model outputs were clipped over the study area to calculate annual climate change signals, which were subsequently superimposed on a local reference period time series of observed data as described in Sections 4.1 and 4.2. Since negative projections can occur with the anomalies, the proportional anomaly was calculated for rainfall. The delta approach removes large parts of the model bias, which cancels out in the climate change signals. Based on these, the annual change can be calculated (assuming linear change) and used directly to generate transient time series to force the models. The limitation of the approach is that the inter-annual variability and annual cycle are neglected, since these climate characteristics are inherited from the observations. There are other statistical techniques available, such as quantile mapping, that can be used to address the issue [26], but they require analysis of daily GCM outputs, which was beyond the scope of this study, and additional corrections are required to account for changes in wet day frequencies.

\subsection{Observational Data}

APHRODITE's Water Resources data (Asian Precipitation—Highly—Resolved Observational Daily Integration 
Towards Evaluation of Water Resources, www.chikyu.ac.jp/precip/) were taken as the reference period data for rainfall [27] and temperature [28]. These high-resolution daily gridded precipitation datasets are the only longterm product currently available on a continental scale. The gridded datasets are based on rain-gauge observations collected from a large number of stations and have substantially improved the depiction of the areal distribution and variability of rainfall over the Himalayas. APHRODITE rainfall (version V1101) high resolution gridded datasets at a resolution of $0.25^{\circ}$ latitude and $0.50^{\circ}$ longitude are available for the period 1951 to 2007 for the monsoon Asia domain $\left(60^{\circ}-150^{\circ} \mathrm{E}, 15^{\circ}-55^{\circ} \mathrm{N}\right)$; and temperature (version V1101R2) gridded datasets for the period 1961-2007 for the same domain. In the present analysis, the reference period was taken from 1961 to 1990.

\section{Results}

The Koshi basin is heavily influenced by the monsoon; about $80 \%$ of annual total rainfall falls in the monsoon season (June to September).Although the winter rainfall (December, January, February) is quite meagre, it is very important for the winter crops. Therefore a seasonal analysis was carried out for rainfall and temperature distribution in the monsoon and winter seasons.

\subsection{Precipitation}

Figure 3 shows the spatial distribution of rainfall in summer and winter for the reference period derived from the APHRODITE data. The maximum rainfall falls in the middle mountain areas of the basin. The peak rainfall areas in the monsoon season (Figure 3(a)) lie in the western parts of the southern slopes of the Himalayan belt. There is a sharp rainfall gradient to the north towards the trans-Himalaya, but some rain-bearing clouds do reach this area and provide some rain. The much smaller amount of precipitation in the winter season shows a similar pattern of distribution (Figure 3(b)).

Table 2 shows the seasonal rainfall statistics for the whole basin and the different physiographic zones. About $80 \%$ of the precipitation occurs during the monsoon season with an annual average for the basin of $1025 \mathrm{~mm}$. There are marked differences in the precipitation pattern between the regions. The highest rainfall is in the middle mountains area, with about $1530 \mathrm{~mm}$ received from approximately 190 days. The trans-Himalayan area is relatively dry with only $421 \mathrm{~mm}$ (standard deviation $59 \mathrm{~mm}$ ) from 113 days.

\subsection{Temperature}

Figure 4 shows the seasonal distribution of average summer (June to September) and winter (December to February) temperatures for the reference period. The temperature shows a progressively decreasing trend from south
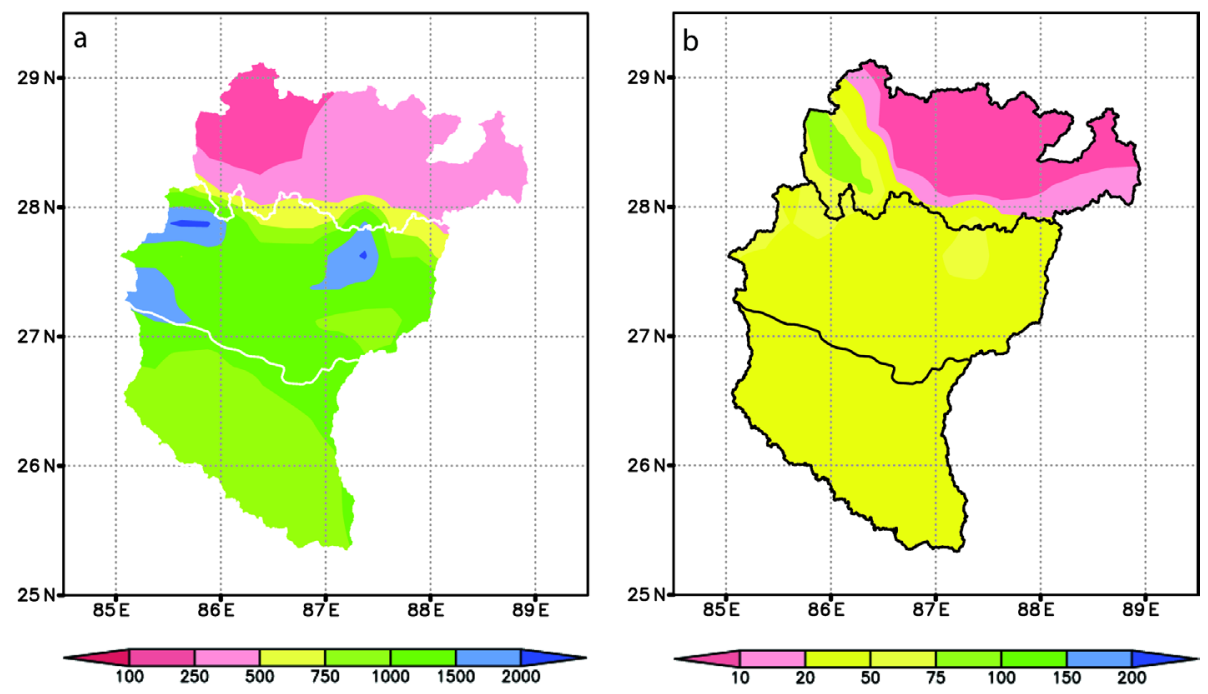

Figure 3. Seasonal rainfall in mm for the reference period 1961-1990: (a) summer (JuneSeptember) and (b) winter (December-February). 
Table 2. Seasonal and annual rainfall for the reference period (1961-1990).

\begin{tabular}{|c|c|c|c|c|c|c|c|c|c|c|c|c|}
\hline \multirow[b]{2}{*}{ Rainfall (mm) } & \multicolumn{4}{|c|}{ Seasonal mean } & \multirow[b]{2}{*}{ Annual } & \multirow{2}{*}{$\begin{array}{c}\text { Rainy } \\
\text { days }\end{array}$} & \multicolumn{6}{|c|}{ Standard deviation } \\
\hline & DJF & MAM & JJAS & ON & & & DJF & MAM & JJAS & ON & Annual & $\begin{array}{c}\text { Rainy } \\
\text { days }\end{array}$ \\
\hline Trans-Himalaya & 20 & 50 & 327 & 24 & 421 & 113 & 11.2 & 15.8 & 49.3 & 16.8 & 59.3 & 9 \\
\hline Middle mountains & 35 & 206 & 1210 & 79 & 1530 & 189 & 23.2 & 48.9 & 113 & 43.8 & 145.7 & 14 \\
\hline Southern plains & 22 & 102 & 891 & 72 & 1087 & 130 & 14.7 & 46.8 & 192 & 59.1 & 213.7 & 14 \\
\hline Whole basin & 26 & 122 & 818 & 58 & 1025 & 171 & 14.0 & 35.4 & 93.0 & 36.4 & 115.4 & 13 \\
\hline$\%$ of annual & 2.5 & 11.9 & 79.8 & 5.7 & & & & & & & & \\
\hline
\end{tabular}

Note: DJF = December, January, February (winter); MAM = March, April, May (pre-monsoon); JJAS = June, July, August, September (summer); $\mathrm{ON}=$ October, November (post-monsoon).

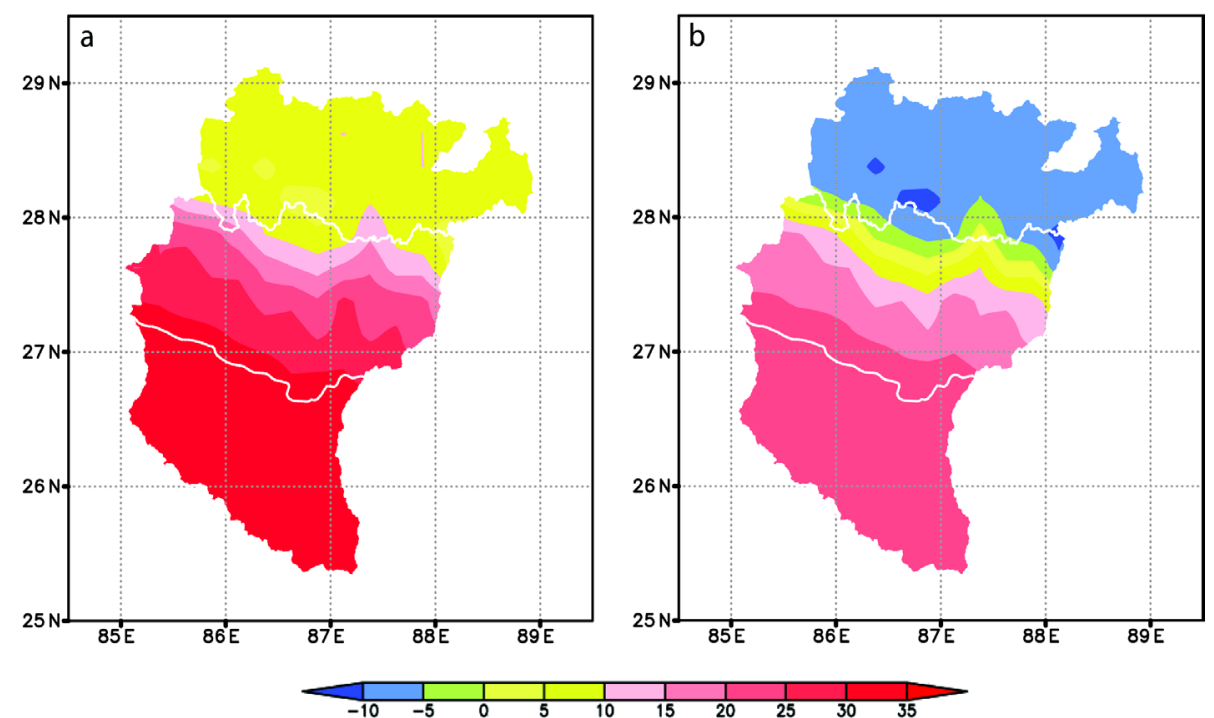

Figure 4. Seasonal distribution of average temperature in ${ }^{\circ} \mathrm{C}$ for the reference period 19611990: (a) summer (June-September) and (b) winter (December-February).

to north which reflects the increasing elevation.

Table 3 shows the seasonal statistics for average temperature for the whole basin and the different physiographic zones. In the plains areas, the pre monsoon and summer seasons have a similar temperature of around $33^{\circ} \mathrm{C}$, while in the trans Himalaya only the summer is warm. In winter, the average temperature ranges from $-7.1^{\circ} \mathrm{C}$ in the trans-Himalaya to $13.8^{\circ} \mathrm{C}$ in the plains. The summer season has the lowest standard deviation, and winter the highest.

\section{Future Projections}

\subsection{Rainfall}

Figure 5 shows the changes in rainfall projected by the different GCMs for the RCP4.5 scenario. GISS-E2-Rr4i1p1 (Figure 5(a)) and IPSL-CMA5A-LR-r3i1p1 (Figure 5(c)) projected an increase in rainfall by 5\% - 25\% and 10\% - >25\%, respectively, for almost all the basin; CanESM2-r4i1p1 (Figure 5(d)) projected a decrease in rainfall by up to $10 \%$ over some areas in the middle mountains and southern plains; and IPSL-CMA5A-LR-r4i1p1 (Figure 5(b)) projected a decrease in rainfall up to $25 \%$ over most parts of the middle mountains and transHimalaya and $10 \%$ over parts of the southern plains, together with an increase in the border area between the middle mountains and trans-Himalaya. The ensemble average projection (Figure 5(e)) shows an overall increase in precipitation with a very small area of decreased precipitation in the middle mountains. 
Table 3. Seasonal and annual average temperatures for the reference period (1961-1990).

\begin{tabular}{|c|c|c|c|c|c|c|c|c|c|c|}
\hline \multirow{2}{*}{$\begin{array}{c}\text { Average } \\
\text { temperature }\left({ }^{\circ} \mathrm{C}\right)\end{array}$} & \multicolumn{5}{|c|}{ Seasonal mean } & \multicolumn{5}{|c|}{ Standard deviation } \\
\hline & DJF & MAM & JJAS & $\mathrm{ON}$ & Annual & DJF & MAM & JJAS & ON & Annual \\
\hline Trans-Himalaya & -7.1 & 0.4 & 7.7 & -1.3 & -0.1 & 1.2 & 1.0 & 0.5 & 1.1 & 0.7 \\
\hline Middle mountains & 6.5 & 20.1 & 22.2 & 17.8 & 16.7 & 1.5 & 1.0 & 0.5 & 0.9 & 0.6 \\
\hline Southern plains & 13.8 & 32.9 & 32.6 & 29.1 & 27.1 & 1.9 & 1.1 & 0.7 & 1.2 & 0.7 \\
\hline Whole basin & 3.7 & 16.8 & 20.0 & 14.5 & 13.8 & 1.4 & 0.8 & 0.4 & 0.6 & 0.5 \\
\hline
\end{tabular}

Note: DJF = December, January, February (winter); MAM = March, April, May (pre-monsoon); JJAS = June, July, August, September (summer); $\mathrm{ON}=$ October, November (post-monsoon).
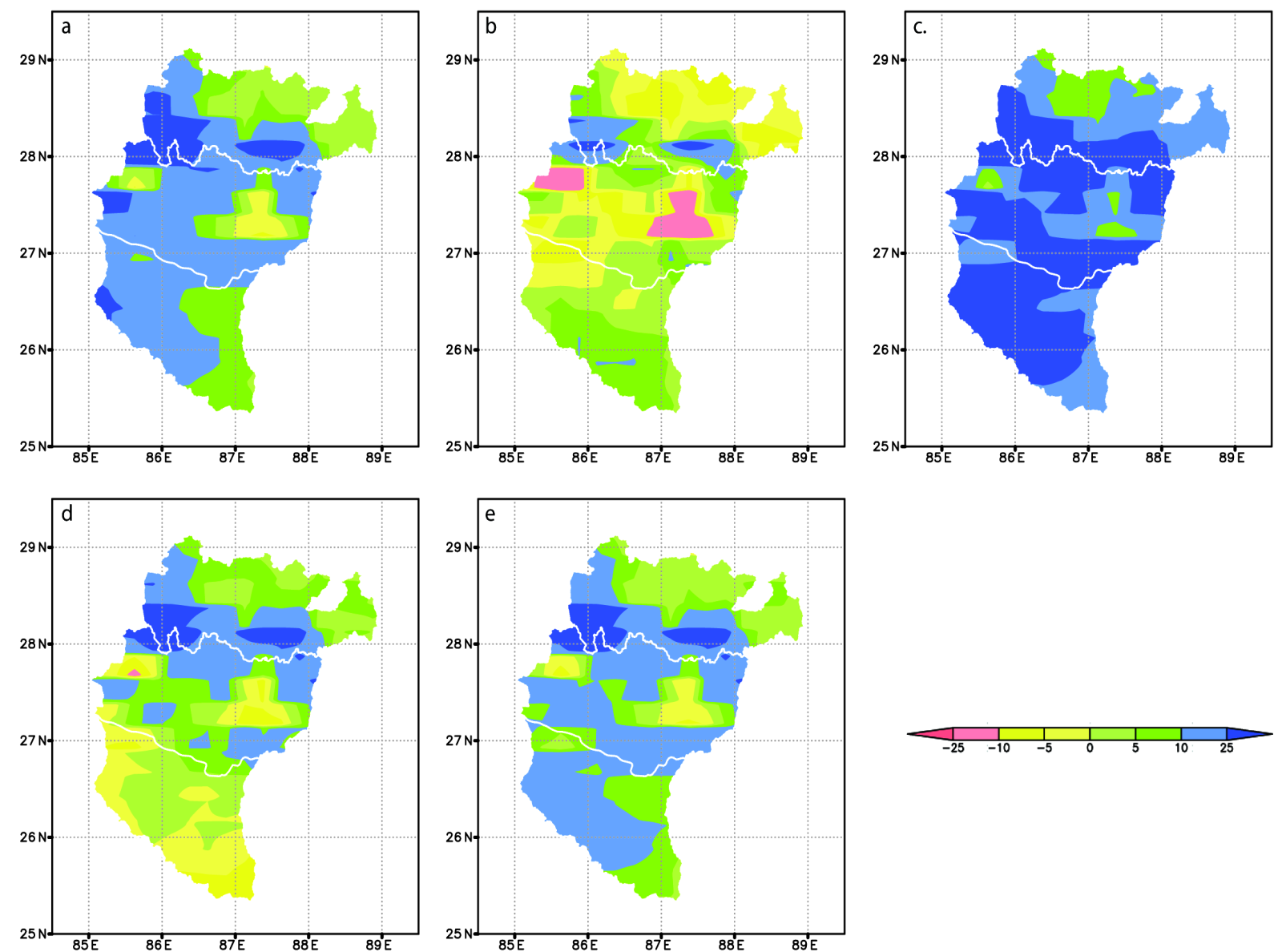

Figure 5. Projected changes in rainfall (\%) during the summer season (June-September) in 2021-2050 with respect to the reference period 1961-1990 with different GCMs under RCP4.5: (a) GISS-E2-R-r4i1p1, (b) IPSL-CMA5A-LR-r4i1p1, (c) IPSL-CMA5A-LR-r3i1p1, (d) CanESM2-r4i1p1, and (e) ensemble average of all four GCMs.

Figure 6 shows the changes in rainfall projected by the different GCMs for the RCP8.5 scenario. GFDLESM2G-r1i1p1 (Figure 6(a)) projected a decrease in rainfall by up to $25 \%$ over small patch areas in the east and west areas of the middle mountains and by up to $10 \%$ over the eastern part of the southern plains. The other three GCMs (IPSL-CM5A-LR-r4i1p1 (Figure 6(b)), CSIRO-Mk3-6-0-r3i1p1 (Figure 6(c)), and CanESM2-r4i1p1 (Figure 6(d))) projected an increase in rainfall over almost all the basin. The ensemble average projection (Figure 6(e)) shows an increase in rainfall from 5\% - 25\% over most of the area and more than $25 \%$ in the border area between the middle mountains and trans-Himalaya.

Figure 7 shows the ensemble average projections for RCP4.5 and RCP8.5 for winter. The projections show 

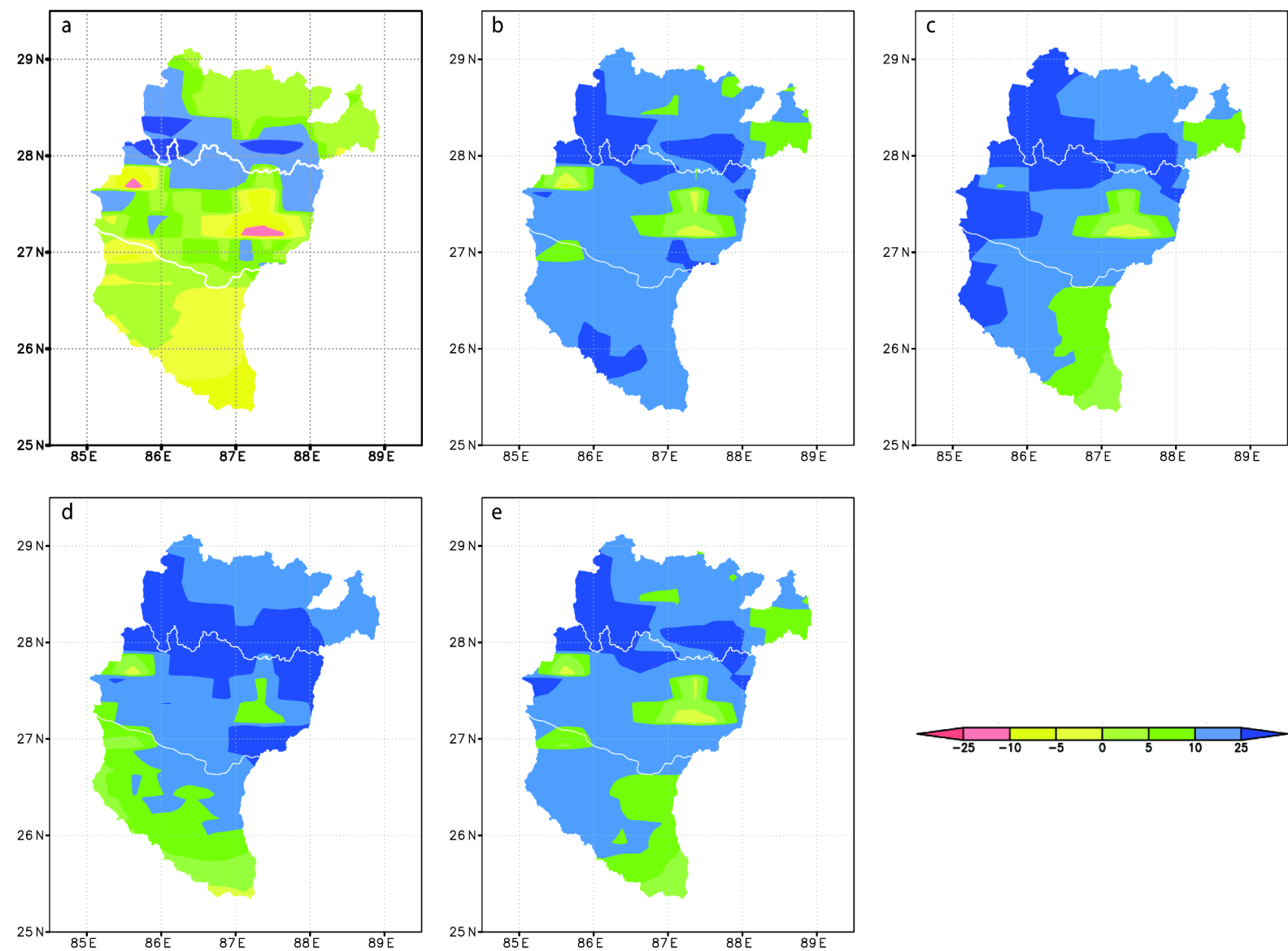

Figure 6. Projected changes in rainfall (\%) during summer season (June-September) in 2021-2050 with respect to the reference period 1961-1990 with different GCMs under RCP8.5: (a) GFDL-ESM2G-r1i1p1, (b) IPSL-CM5A-LR-r4i1p1, (c) CSIRO-Mk3-6-0-r3i1p1 and (d) CanESM2-r4i1p1 and (e) Ensemble average of the above four GCMs.

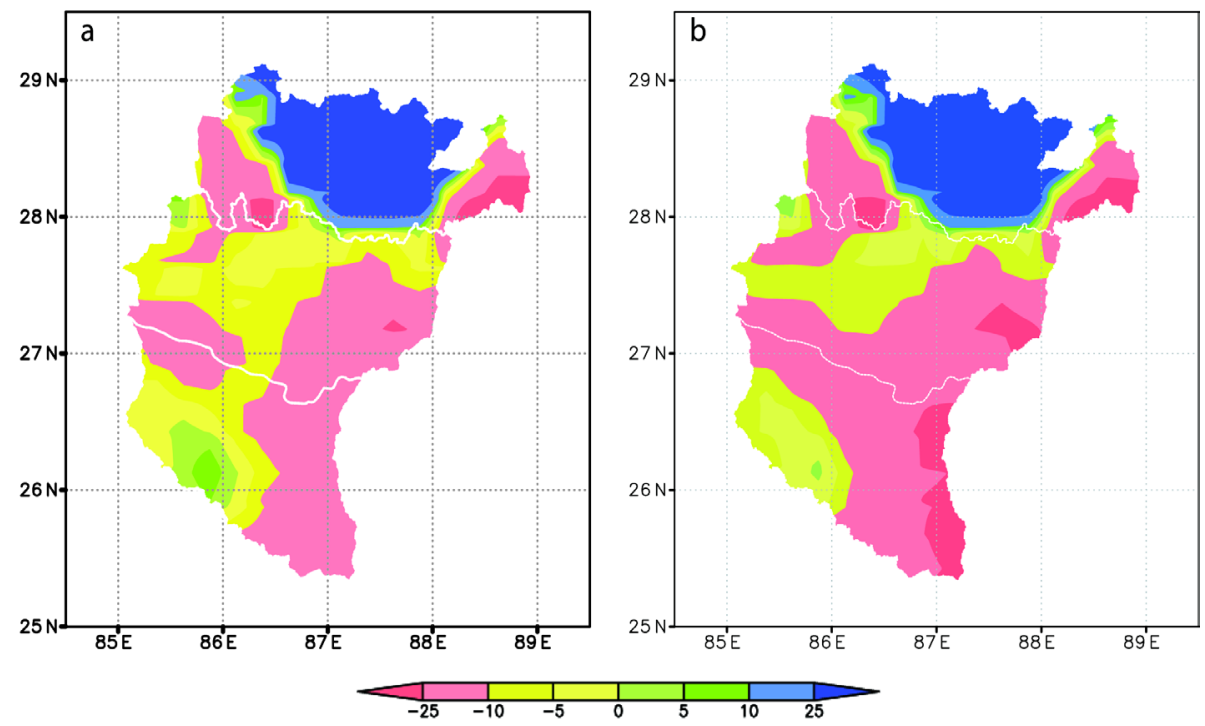

Figure 7. Ensemble projected changes in rainfall in \% during the winter season (DecemberFebruary) in 2021-2050 with respect to the reference period 1961-1990 under (a) RCP4.5 and (b) RCP8.5. 
an increase in rainfall over the trans-Himalaya and decrease over the middle mountains and southern plains for both scenarios. The total rainfall during this season is very low and small increment could reflect in a larger percentage changes.

Figure 8 shows average monthly rainfall for the reference period, and the ensemble average projections under the RCP4.5 and RCP8.5 scenarios, for the different physiographic zones and the basin overall. The RCP8.5 projections for the whole basin were slightly higher than those under RCP4.5 in May, July, August, and September, and slightly lower in June and October. Overall under both scenarios the wet months (July, August, and September) are getting wetter, particularly in the middle mountains and the southern plains.

Figure 9 shows the ensemble future projection of rainfall compared to the reference period for the different physiographic zones and the whole basin in summer and winter for the two scenarios. Rainfall is projected to increase in summer for all three physiographic zones, whereas in winter rainfall is projected to increase over the
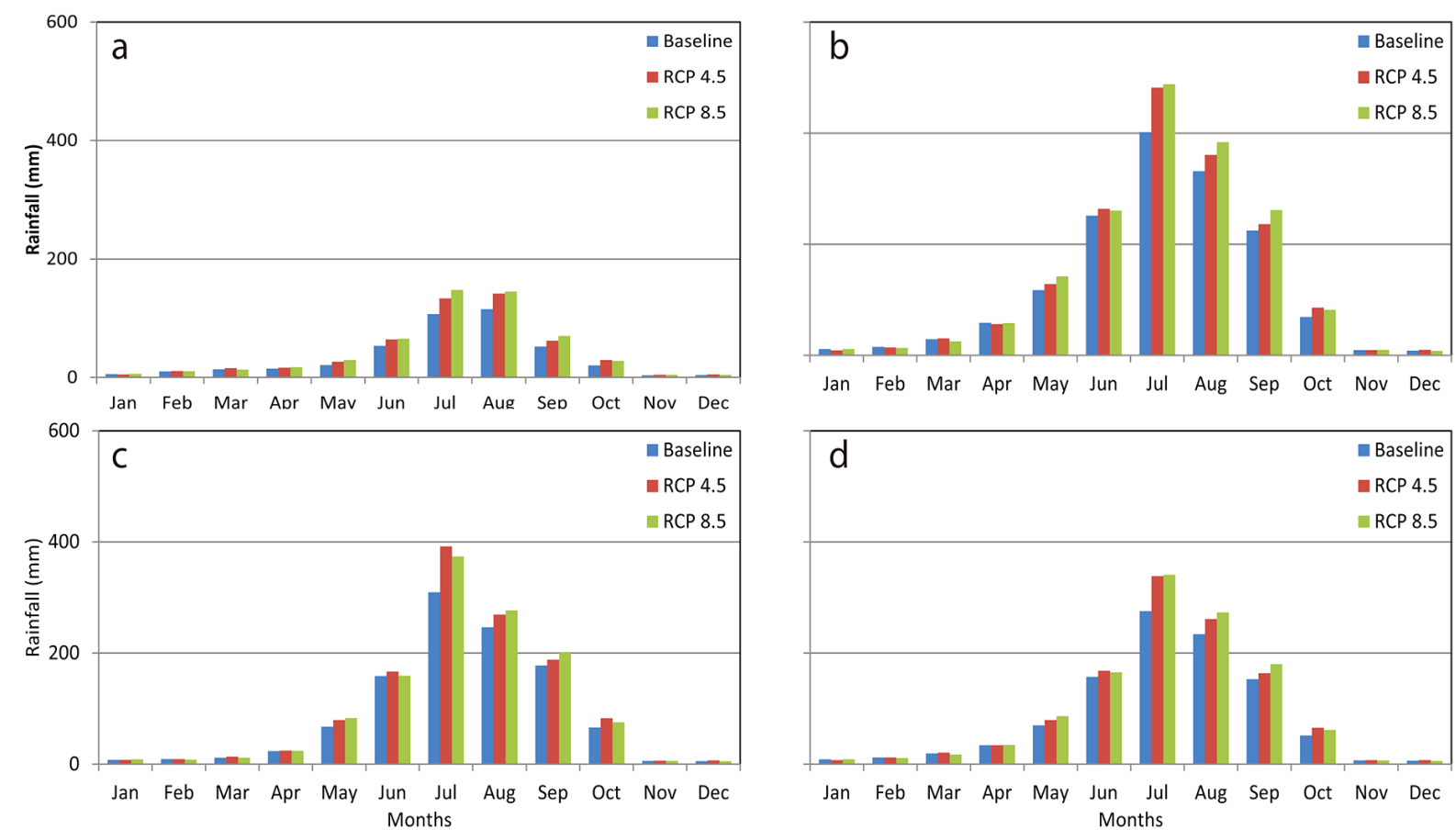

Figure 8. Ensemble projected average rainfall for the period 2021-2050: (a) trans-Himalaya (b) middle mountains (c) southern plains, and (d) whole Koshi basin (blue = reference period; red = RCP4.5; green = RCP8.5).
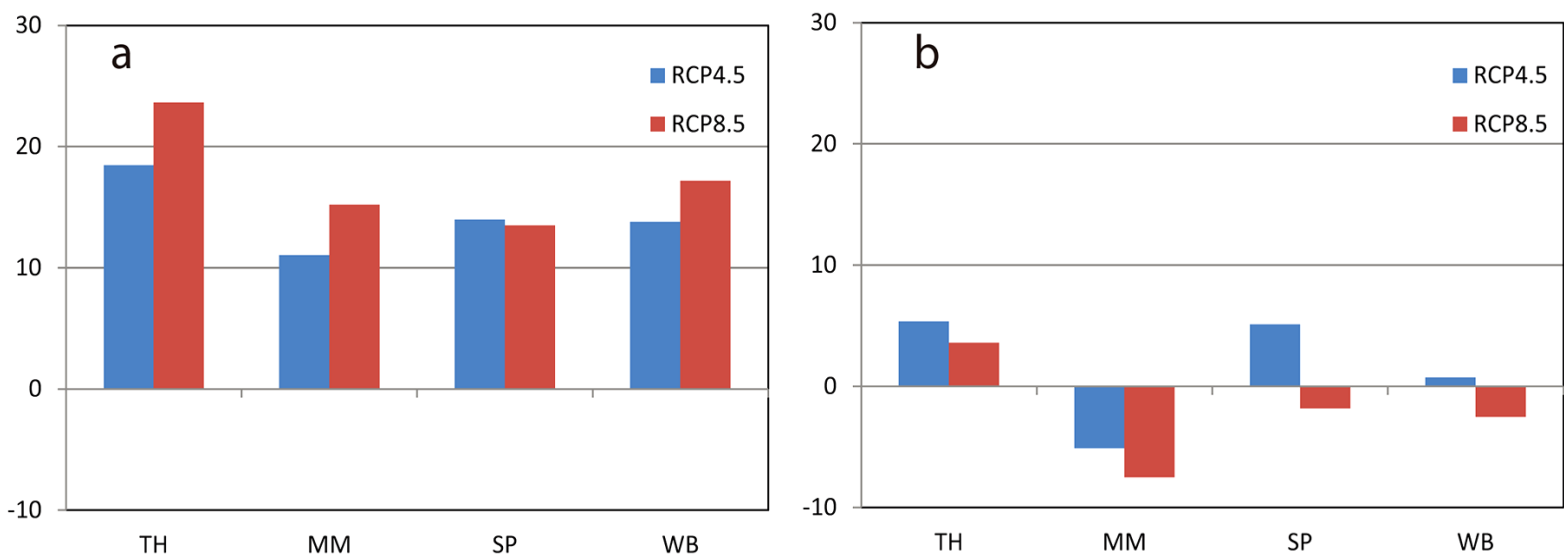

Figure 9. Ensemble projected changes in rainfall in \% in 2021-2050 with respect to the reference period 1961-1990 for the different physiographic zones in (a) summer and (b) winter ( $\mathrm{TH}=$ trans-Himalaya; $\mathrm{MM}=$ middle mountains; $\mathrm{SP}=$ southern plains; WB = whole basin). 
trans Himalaya and decrease in the middle mountains. An average increase in annual precipitation of $14 \%$ for the whole basin is projected by RCP4.5 and 17\% by RCP8.5, indicating a slight increase in overall future water availability. The highest percentage change is projected over the trans-Himalayan area, 18\% for RCP4.5 and $24 \%$ for RCP8.5.

\subsection{Temperature}

Figure 10 and Figure 11 show the change in average temperature in summer projected by the different GCMs for the projection period 2021-2050 compared to the reference period under RCP4.5 and RCP8.5. All areas show warming under both scenarios under all GCMs but there are differences in magnitude. Under RCP4.5, warming is highest over the middle mountains, with increases of $2^{\circ} \mathrm{C}-5^{\circ} \mathrm{C}$. All GCMs show lower warming over the southern plains, with the least warming $\left(0^{\circ} \mathrm{C}-1^{\circ} \mathrm{C}\right)$ shown by GISS-E2-R-r4i1p1 (Figure 10(a)); and the most $\left(1^{\circ} \mathrm{C}-3^{\circ} \mathrm{C}\right.$ ) by CanESM2-r4i1p1 (Figure 10(d)). The temperature increase over the trans-Himalayan area was generally between $1^{\circ} \mathrm{C}$ and $3^{\circ} \mathrm{C}$, higher than for the southern plains but lower than for the high Himalaya and middle mountains. IPSL-CMA5A-LR-r3i1p1 (Figure 10(b)) showed the greatest increases, with projections of more than $3^{\circ} \mathrm{C}-4^{\circ} \mathrm{C}$ increase over a few areas in the extreme north and along the border with the middle mountains. The ensemble average shows a warming of $1^{\circ} \mathrm{C}-2^{\circ} \mathrm{C}$ over the southern plains, $2^{\circ} \mathrm{C}-5^{\circ} \mathrm{C}$ over the middle mountains, and $1^{\circ} \mathrm{C}-3^{\circ} \mathrm{C}$ over the trans-Himalaya (Figure 10(e)).

The pattern of warming under the RCP8.5 scenario is similar. Warming is highest over the middle mountains with the greatest increase $\left(2^{\circ} \mathrm{C}-6^{\circ} \mathrm{C}\right)$ shown by CanESM2-r4i1p1-a warm bias GCM (Figure 11(d)), and the least $\left(1^{\circ} \mathrm{C}-4^{\circ} \mathrm{C}\right)$ by CSIRO-Mk3-6-0-r3i1p1-a cold bias GCM (Figure 11(b)). The ensemble average shows
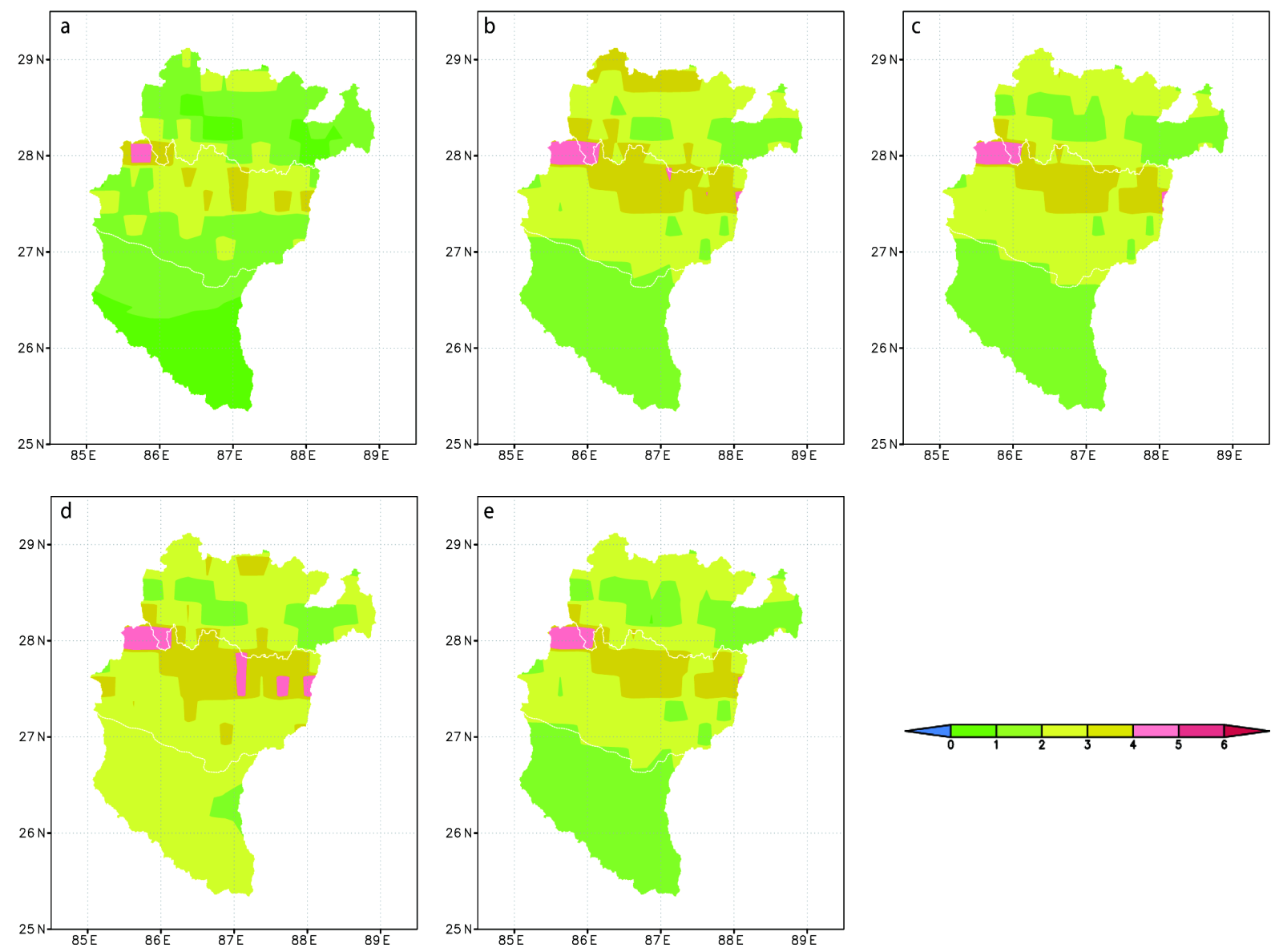

Figure 10. Projected changes in average temperature $\left({ }^{\circ} \mathrm{C}\right)$ during the summer season (June-September) in 2021-2050 with respect to the reference period 1961-1990 with different GCMs under RCP4.5: (a) GISS-E2-R-r4i1p1, (b) IPSL-CMA5ALR-r3i1p1, (c) IPSL-CMA5A-LR-r4i1p1, and (d) CanESM2-r4i1p1, and (e) ensemble average of all four GCMs. 

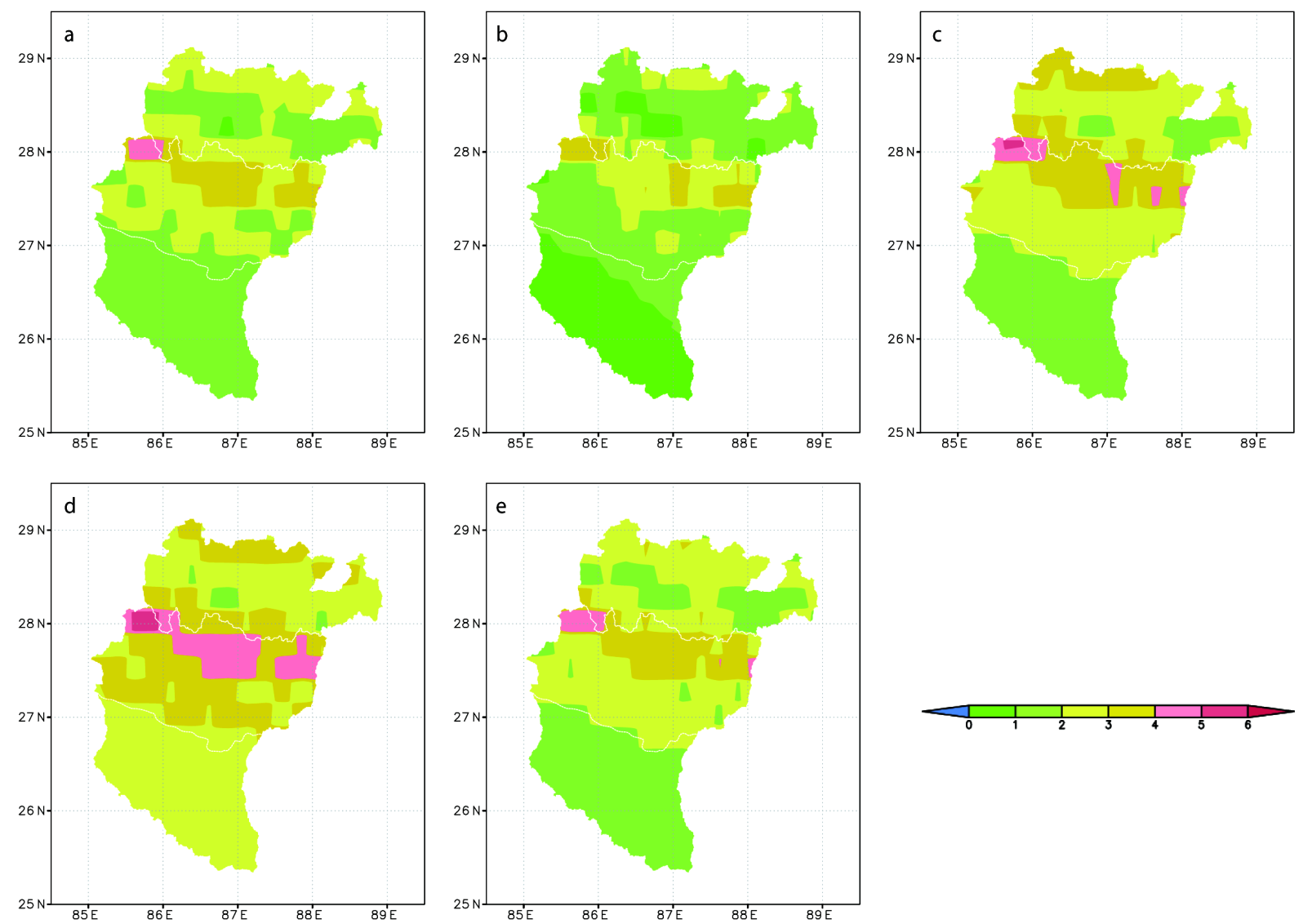

Figure 11. Projected changes in average temperature $\left({ }^{\circ} \mathrm{C}\right)$ during the summer season (June-September) in 2021-2050 with respect to the reference period 1961-1990 with different GCMs under RCP8.5: (a) GFDL-ESM2G-r1i1p1, (b) CSIROMk3-6-0-r3i1p1, (c) IPSL-CM5A-LR-r4i1p1, and (d) CanESM2-r4i1p1, and (e) ensemble average of all four GCMs.

the same range of warming as under RCP4.5 with significantly higher warming over the mountains than the plains: $1^{\circ} \mathrm{C}-2^{\circ} \mathrm{C}$ over the southern plains, $2^{\circ} \mathrm{C}-5^{\circ} \mathrm{C}$ over the middle mountains, and $1^{\circ} \mathrm{C}-3^{\circ} \mathrm{C}$ over the transHimalaya.

Figure 12 shows the changes in average temperature in winter (December-February) projected by the different GCMs for the projection period 2021-2050 compared to the reference period under RCP4.5. As in summer, warming is least over the southern plains $\left(1^{\circ} \mathrm{C}-2^{\circ} \mathrm{C}\right.$ ), intermediate over the trans-Himalaya (mostly $1^{\circ} \mathrm{C}-4^{\circ} \mathrm{C}$ ), and highest over the middle mountains (mostly $2^{\circ} \mathrm{C}-5^{\circ} \mathrm{C}$, with a small area in the northwest exceeding $5^{\circ} \mathrm{C}$ ).

Figure 13 shows the changes in average temperature in winter (December-February) projected by the different GCMs for the projection period 2021-2050 compared to the reference period under RCP8.5. Again warming is least over the southern plains $\left(1^{\circ} \mathrm{C}-3^{\circ} \mathrm{C}\right)$, intermediate over the trans-Himalaya (mostly $1^{\circ} \mathrm{C}-4^{\circ} \mathrm{C}$ ), and highest over the middle mountains (mostly $2^{\circ} \mathrm{C}-5^{\circ} \mathrm{C}$ ), but although the ranges are similar, overall all models show slightly higher warming than under RCP4.5 with a larger area covered by the higher temperatures in the range.

Figure 14 shows the average monthly temperature for the reference period and the ensemble average projections under the RCP4.5 and RCP8.5 scenarios for the different physiographic zones and the basin overall. The projected temperatures under RCP8.5 are either equal to or slightly higher than those under RCP4.5 except in July in the middle mountains, September in the southern plains, and September for the whole basin, when the RCP4.5 projection is fractionally higher $\left(0.1^{\circ} \mathrm{C}\right)$ than for RCP8.5.

Figure 15 shows the ensemble average projected changes in temperature compared to the reference period for the different physiographic zones and the whole basin in summer and winter for the RCP4.5 and RCP8.5 scenarios. Overall warming was higher in winter with an average increase of $2.4^{\circ} \mathrm{C}$ under RCP4.5 or $2.6^{\circ} \mathrm{C}$ under RCP8.5 projected over the entire basin. Warming is highest over the middle mountains and trans-Himalaya, and lowest over the southern plains. 

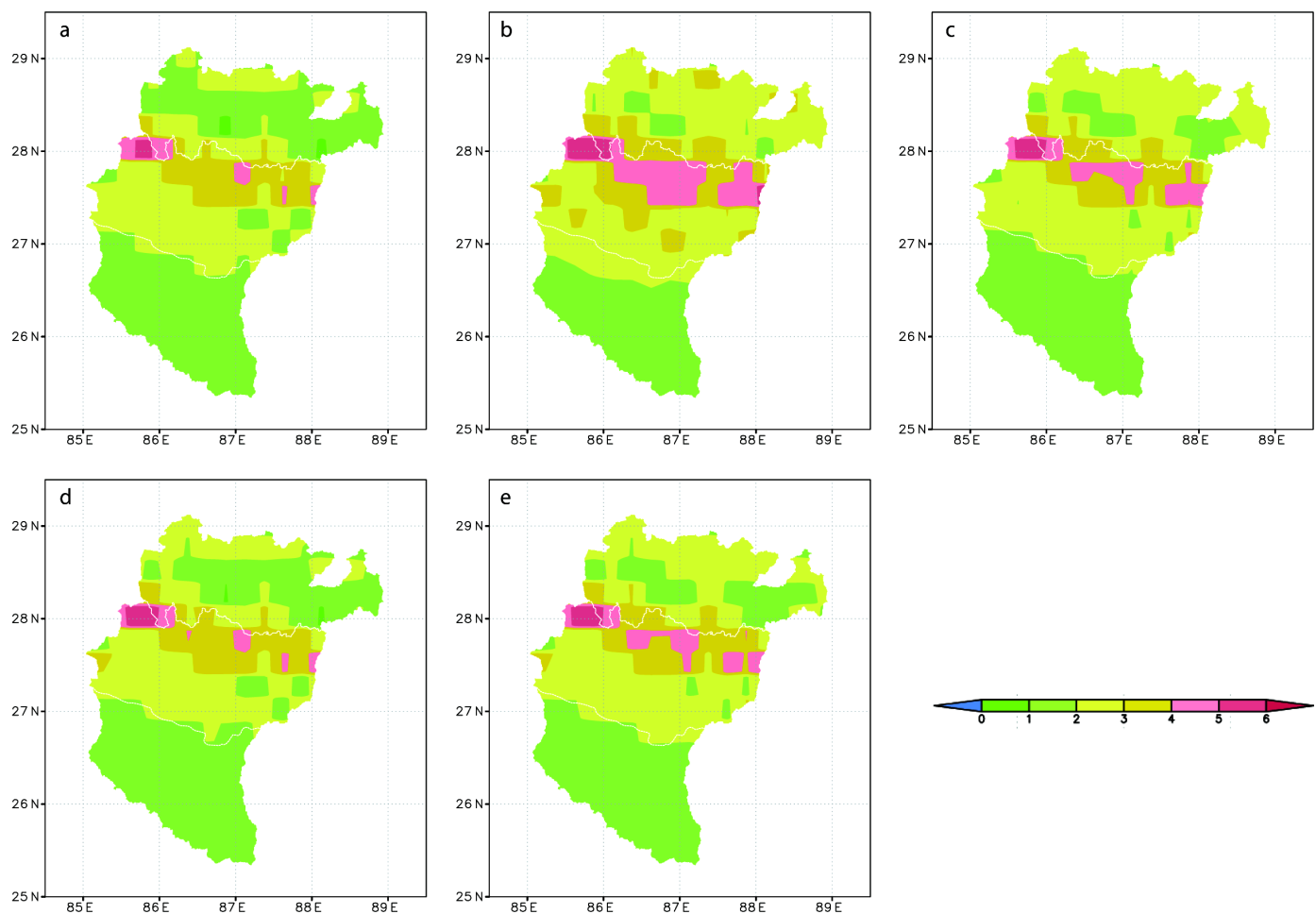

Figure 12. Projected changes in average temperature $\left({ }^{\circ} \mathrm{C}\right.$ ) during the winter season (December-February) in 2021-2050 with respect to the reference period 1961-1990 with different GCMs under RCP4.5: (a) GISS-E2-R-r4i1p1, (b) IPSLCMA5A-LR-r3i1p1, (c) IPSL-CMA5A-LR-r4i1p1, (d) CanESM2-r4i1p1, and (e) ensemble average of all four GCMs.
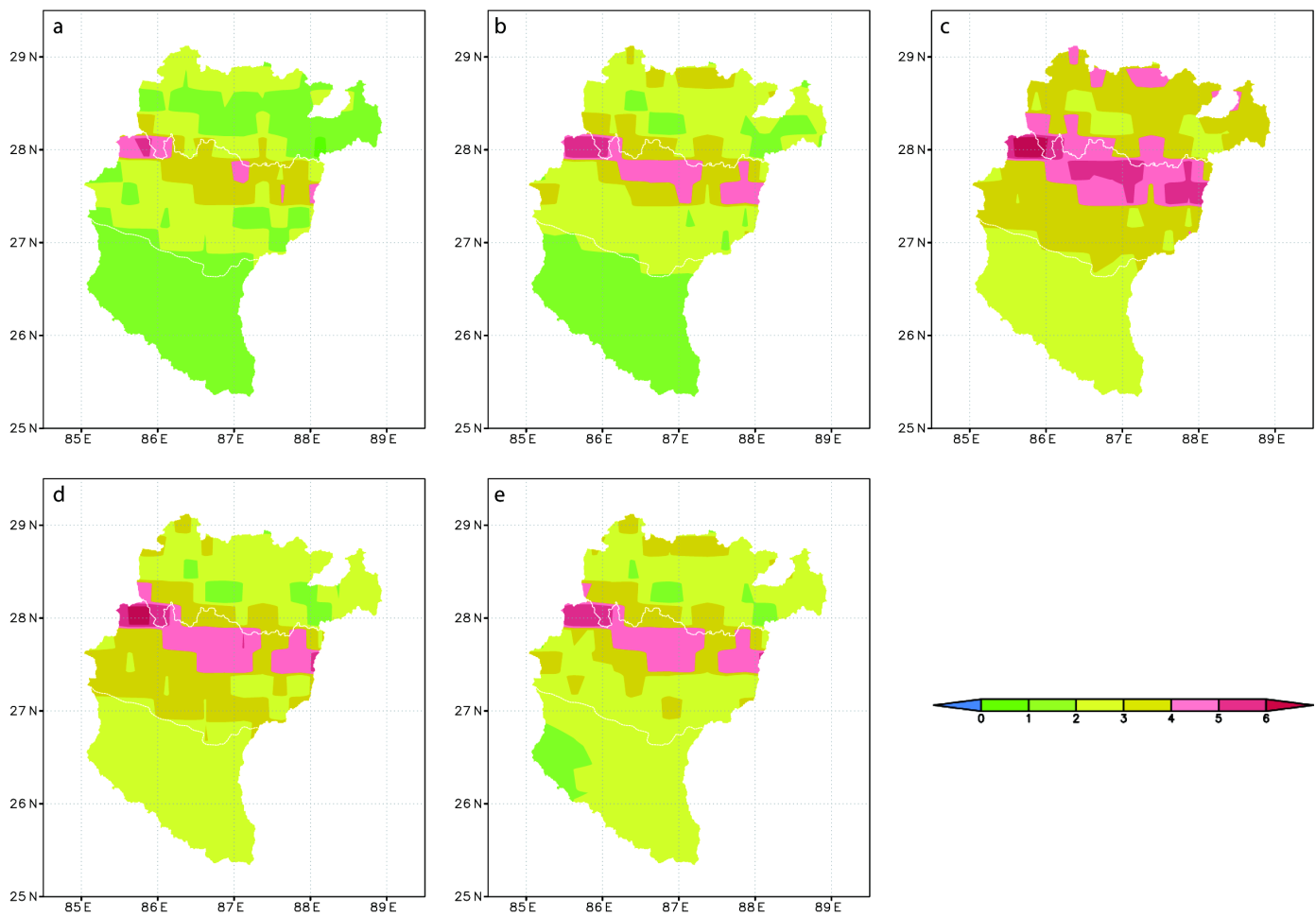

Figure 13. Changes in average temperature $\left({ }^{\circ} \mathrm{C}\right.$ ) during the winter season (December-February) in 2021-2050 with respect to the reference period 1961-1990 with different GCMs under RCP8.5: (a) GFDL-ESM2G-r1i1p1, (b) CSIRO-Mk3-6-0r3i1p1, (c) IPSL-CM5A-LR-r4i1p1, (d) CanESM2-r4i1p1, and (e) ensemble average of all four GCMs. 

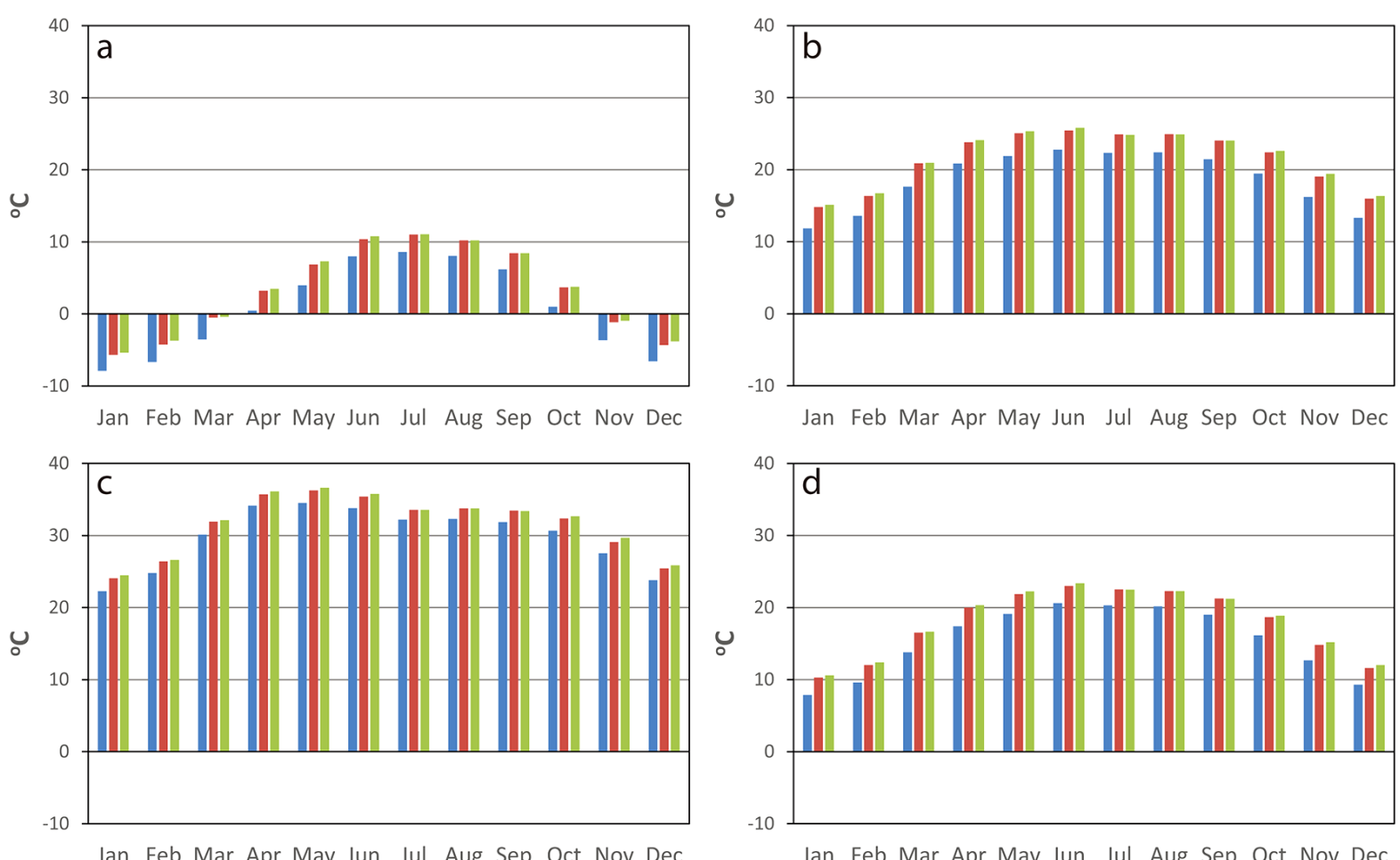

Figure 14. Ensemble projected average temperature $\left({ }^{\circ} \mathrm{C}\right.$ ) for the period 2021-2050: (a) trans-Himalaya (b) middle mountains (c) southern plains, and (d) whole Koshi basin (blue = reference period; red = RCP4.5; green = RCP8.5).
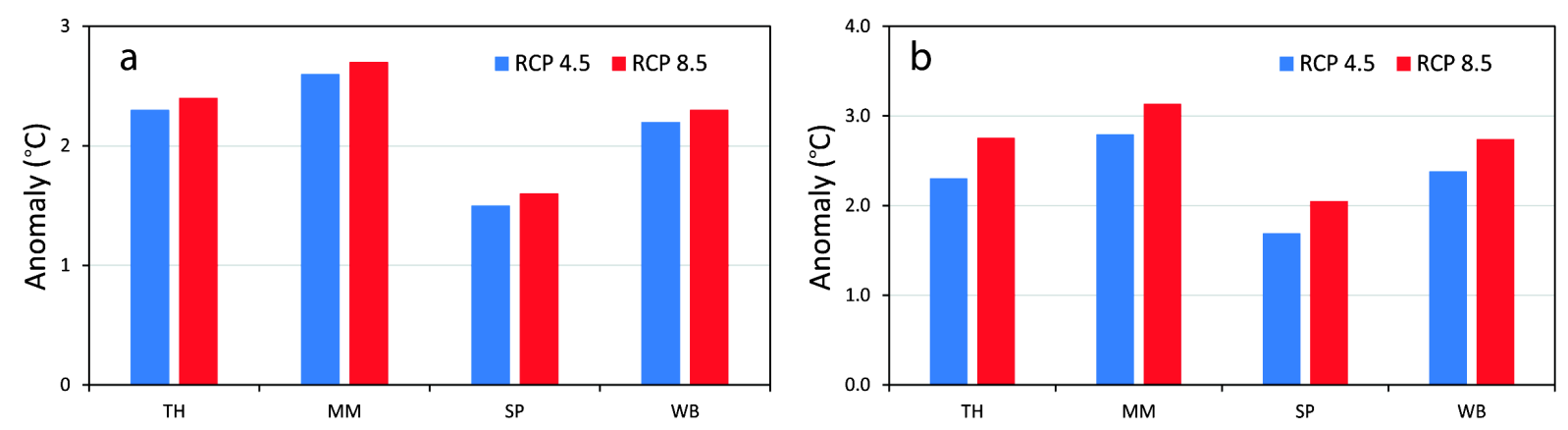

Figure 15. Ensemble projected temperature anomaly in $\left({ }^{\circ} \mathrm{C}\right)$ in $2021-2050$ with respect to the reference period 1961-1990 for the different physiographic zones in (a) summer and (b) winter ( $\mathrm{TH}=$ trans-Himalaya; $\mathrm{MM}=$ middle mountains; $\mathrm{SP}=$ southern plains; $\mathrm{WB}$ = whole basin).

\section{Conclusions}

The GCM climate projections for the Koshi river basin for RCP4.5 and RCP 8.5 indicated some marked changes in precipitation and temperature with variations in the different physiographic zones. The outputs for RCP4.5 suggest an increase in summer rainfall, with slight differences between the models. The increase ranges from 5\% to $25 \%$, with higher values in the high mountain ranges. The projections for RCP 8.5 suggest a greater increase in the northern areas, and some decrease in the southern plains. The projections for winter suggest a slight increase in rainfall in the north and a decrease in the south. There is some indication that overall the monsoon season could get wetter and winter drier.

The study suggests that the basin is likely to experience overall warming by the middle of the century. The greatest warming is expected over the high altitude regions, while the plain areas are projected to have low or no warming. The projections under RCP4.5 suggest greater warming during winter. Warming under RCP 8.5 is no greater than under RCP4.5, but the area with higher warming is larger. 
The changes suggest that there may be an increased supply of water overall due to increased rainfall and increased snow and glacier melt, but with a reduced supply in winter. The approach used in this study cannot identify short-term variations or changes in extremes, but the increased rainfall during summer could indicate the possibility of more, and more intense, floods. This issue needs to be investigated as flood and droughts are important drivers and have a marked impact on people's livelihoods in the basin and beyond.

\section{Acknowledgements}

This study was undertaken under ICIMOD’s Koshi Basin Programme, which is funded in part by the Australian Government through the Sustainable Development Investment Portfolio for South Asia in Nepal. The study is also supported by core funding from ICIMOD provided by the Governments of Afghanistan, Australia, Austria, Bangladesh, Bhutan, China, India, Myanmar, Nepal, Norway, Pakistan, Switzerland, and by the United Kingdom's Department for International Development (DFID), through their support of core research at ICIMOD.

We acknowledge the World Climate Research Program's Working Group on Coupled Modeling, which is responsible for CMIP5, and we thank the climate modelling groups for producing and making available their model output. We thank Dr Walter Immerzeel and Mr Arthur Lutz, Future Water, The Netherlands for providing the downscaled CMIP5 data for this analysis.

\section{Disclaimer}

The views expressed in this work are those of the authors and are not necessarily attributable to their organizations and do not necessarily represent those of the Australian Government.

\section{References}

[1] Shrestha, A.B. and Aryal, R. (2011) Climate Change in Nepal and Its Impact on Himalayan Glaciers. Regional Environmental Change, 11, S65-S77. http://dx.doi.org/10.1007/s10113-010-0174-9

[2] Singh, S.P., Bassignana-Khadka, I., Karky, B.S. and Sharma, E. (2011) Climate Change in the Hindu Kush-Himalayas: The State of Current Knowledge. ICIMOD, Kathmandu, 88 p.

[3] Chalise, S.R. (1994) Mountain Environments and Climate Change in the Hindu Kush-Himalayas. In: Beniston, M., Ed., Mountain Environments in Changing Climates, Routledge, London, 383-404. http://dx.doi.org/10.4324/9780203424957_chapter_24

[4] Shrestha, M.L. (2000) Interannual Variation of Summer Monsoon Rainfall over Nepal and Its Relation to Southern Oscillation Index. Meteorology and Atmospheric Physics, 75, 21-28. http://dx.doi.org/10.1007/s007030070012

[5] Shrestha, A.B., Cameron, P.W., Jack, E.D. and Paul, A.M. (2000) Precipitation Fluctuations in the Nepal Himalaya and Its Vicinity and Relationship with Some Large Scale Climatological Parameters. International Journal of Climatology, 20, 317-327. http://dx.doi.org/10.1002/(SICI)1097-0088(20000315)20:3<317::AID-JOC476>3.0.CO;2-G

[6] Arora, M., Singh, P., Goel, N.K. and Singh, R.D. (2006) Spatial Distribution and Seasonal Variability of Rainfall in a Mountainous Basin in the Himalayan Region. Water Resources Management, 20, 489-508. http://dx.doi.org/10.1007/s11269-006-8773-4

[7] Ives, J.D. and Messerli, B. (1989) The Himalayan Dilemma: Reconciling Development and Conservation. The United Nations University, Routledge, London. http://dx.doi.org/10.4324/9780203169193

[8] Eriksson, M., Xu, J., Shrestha, A.B., Vaidya, R.A., Nepal, S. and Sandström, K. (2009) The Changing Himalayas: Impact of Climate Change on Water Resources and Livelihoods in the Greater Himalayas. ICIMOD, Kathmandu, 22 p.

[9] Solomon, S., Qin, D., Manning, M., Chen, Z., Marquis, M., Averyt, K.B., Tignor, M. and Miller, H.L., Eds. (2007) IPCC, 2007: Climate Change 2007: The Physical Science Basis. Contribution of Working Group I to the Fourth Assessment Report of the Intergovernmental Panel on Climate Change. Cambridge University Press, Cambridge, United Kingdom and New York, NY, USA, 996 p.

[10] Flint, L.E. and Flint, A.L. (2012) Simulation of climate change in San Francisco Bay Basins, California: Case studies in the Russian River Valley and Santa Cruz Mountains: U.S. Geological Survey Scientific Investigations Report 2012-5132, 55 p.

[11] Lutz, A.F., Immerzeel. W.W., Shrestha, A.B. and Bierkens, M.F.P. (2014) Consistent Increase in High Asia’s Runoff Due to Increasing Glacier Melt and Precipitation. Nature Climate Change, 4, 587-592. http://dx.doi.org/10.1038/nclimate2237

[12] Akhtar, M., Ahmad, N. and Booij, M.J. (2009) Use of Regional Climate Model Simulations as Input for Hydrological Models for the Hindukush-Karakorum-Himalaya Region. Hydrology and Earth System Sciences, 13, 1075-1089. 
http://dx.doi.org/10.5194/hess-13-1075-2009

[13] Immerzeel, W.W., van Beek, L.P.H. and Bierkens, M.F.P. (2010) Climate Change Will Affect the Asian Water Towers. Science, 328, 1382-1385. http://dx.doi.org/10.1126/science.1183188

[14] Nepal, S. (2012) Evaluating Upstream-Downstream Linkages of Hydrological Dynamics in the Himalayan Region. PhD Thesis, Friedrich Schiller University, Jena.

[15] Shrestha, A.B., Eriksson, M., Mool, P., Ghimire, P., Mishra, B. and Khanal, N.R. (2010) Glacial Lake Outburst Flood Risk Assessment of Sun Koshi Basin, Nepal. Geomatics, Natural Hazards and Risk, 1, 157-169. http://dx.doi.org/10.1080/19475701003668968

[16] Holeman, J.N. (1968) The Sediment Yield of Major Rivers of the World. Water Resources Research, 4, 737-747. http://dx.doi.org/10.1029/WR004i004p00737

[17] Sharma, K.P. (1997) Impact of Land-Use and Climatic Changes on Hydrology of the Himalayan Basin: A Case Study of the Kosi Basin. Ph.D. Thesis, University of New Hampshire, Durham.

[18] Latrubesse, E.M., Stevaux, J.C. and Sinha, R. (2005) Tropical Rivers. Geomorphology, 70, 187-206. http://dx.doi.org/10.1016/j.geomorph.2005.02.005

[19] Goswami, B.N., Venugopal, V., Sengupta, D., Madhusoodanan, M.S. and Xavier, P.K. (2006) Increasing Trend of Extreme Rain Events over India in a Warming Environment. Science, 314, 1442-1445. http://dx.doi.org/10.1126/science.1132027

[20] Turner, A.G. and Annamalai, H. (2012) Climate Change and the South Asian Summer Monsoon. Nature Climate Change, 2, 587-595. http://dx.doi.org/10.1038/nclimate1495

[21] Stocker, T.F., Qin, D., Plattner, G.-K., Tignor, M., Allen, S.K., Boschung, J., Nauels, A., Xia, Y., Bex, V. and Midgley, P.M., Eds. (2013) IPCC, 2013: Climate Change 2013: The Physical Science Basis. Contribution of Working Group I to the Fifth Assessment Report of the Intergovernmental Panel on Climate Change. Cambridge University Press, Cambridge, United Kingdom and New York, NY, USA, 1535 p.

[22] Moss, R.H., Edmonds, J.A., Hibbard, K.A., Manning, M.R., Rose, S.K., van Vuuren, D.P., Carter, T.R., Emori, S., Kainuma, M., Kram, T., Meehl, G.A., Mitchell, J.F.B., Nakicenovic, N., Riahi, K., Smith, S.J., Stouffer, R.J., Thomson, A.M., Weyant, J.P. and Wilbanks, T.J. (2010) The Next Generation of Scenarios for Climate Change Research and Assessment. Nature, 463, 747-756. http://dx.doi.org/10.1038/nature08823

[23] Arnell, N.W. (1999) The Effect of Climate Change on Hydrological Regimes in Europe: A Continental Perspective. Global Environmental Change, 9, 5-23. http://dx.doi.org/10.1016/S0959-3780(98)00015-6

[24] Déqué, M., Rowell, D.P., Lüthi, D., Giorgi, F., Christensen, J.H., Rockel, B., Jacob, D., Kjellström, E., de Castro, M. and van den Hurk, B. (2007) An Intercomparison of Regional Climate Simulations for Europe: Assessing Uncertainties in Model Projections. Climatic Change, 81, 53-70. http://dx.doi.org/10.1007/s10584-006-9228-x

[25] Kay, A.L., Davies, H.N., Bell, V.A. and Jones, R. (2009) Comparison of Uncertainty Sources for Climate Change Impacts: flood Frequency in England. Climatic Change, 92, 41-63. http://dx.doi.org/10.1007/s10584-008-9471-4

[26] Themeßl, M.J., Gobiet, A. and Heinrich, G. (2011) Empirical-Statistical Downscaling and Error Correction of Regional Climate Models and Its Impact on the Climate Change Signal. Climate, 112, 449-468.

[27] Yatagai, A., Kamiguchi, K., Arakawa, O., Hamada, A., Yasutomi, N. and Kitoh, A. (2012) APHRODITE: Constructing a Long-Term Daily Gridded Precipitation Dataset for Asia Based on a Dense Network of Rain Gauges. Bulletin of the American Meteorological Society, 93, 1401-1415. http://dx.doi.org/10.1175/BAMS-D-11-00122.1

[28] Yasutomi, N., Hamada, A. and Yatagai, A. (2011) Development of a Long-Term Daily Gridded Temperature Dataset and Its Application to Rain/Snow Discrimination of Daily Precipitation. Global Environmental Research, 15, 165-172. 